\title{
Hubungan Antara Kekuatan Lengan Dan Koordinasi Mata-Tangan Terhadap Kemampuan Smash Dalam Permainan Bulutangkis
}

\author{
The Relationship Between Arm Strength And Eye-Hand Coordination \\ Against Smash Ability In Badminton Games
}

\author{
Hasruddin \\ Program Studi Penjaskesrek, STKIP Paris Barantai \\ Jl. Veteran No. 15B Km.2, Kompleks Perikanan, Kota Baru, 72113, Kalimantan Selatan, Indonesia \\ e-mail: Udhinharuna3@gmail.com
}

\begin{abstract}
Abstrak
Penelitain ini adalah jenis penelitian deskriptif. Penelitian ini bertujuan untuk mengetahui: mengetahui hubungan kekuatan lengan dengan Kemampuan smash dalam permainan bulutangkis, mengetahui hubungan koordinasi mata tangan dengan Kemampuan smash dalam permainan bulutangkis pada, mengetahui hubungan antara kekuatan lengan dan koordinasi mata tangan dengan Kemampuan smash dalam permainan bulutangkis. Populasinya adalah siswa kelas VIII SMPN 19 Hulu Sungai Tengah sedangkan Sampel yang digunakan adalah putra kelas VIII SMPN 6 Kotabaru sebanyak 35 orang. Teknik penentuan sampel adalah dengan secara undian dengan cara undian (teknik random sampling). Teknik analisis data yang digunakan adalah analisis deskriptif dan analisis inferensial melalui program SPSS 22 pada taraf signifikan $\alpha 0,05$. Hasil penelitian menunjukkan bahwa; ada hubungan yang signifikan antara kekuatan lengan dengan kemampuan smash dalam permainan bulutangkis sebesar 0,674, ada hubungan yang signifikan antara koordinasi mata tangan dengan kemampuan smash dalam permainan bulutangkis sebesar 0,527, ada hubungan yang signifikan secara bersama-sama antara kekuatan lengan koordinasi mata tangan dengan kemampuan smash dalam permainan bulutangkis Sebesar $\mathrm{F}=22,258$
\end{abstract}

Kata Kunci: Kekuatan lengan, Koordinasi mata tangan, Kemampuan smash.

\section{Abstract}

This research is a descriptive research type. This study aims to see: see the relationship between arm strength and smash ability in badminton, hand eye coordination with smash skills in badminton games, see the relationship between arm strength and hand eye coordination with smash ability in badminton. The population is the eighth grade students of SMPN 19 Hulu Sungai Tengah while the sample used is the seventh grade students of SMPN 6 Kotabaru as many as 35 people. The technique of determining the sample is by means of a lottery (random sampling technique). The data analysis technique used is descriptive analysis and inferential analysis through the SPSS 22 program at a significant level of $\alpha 0.05$. The results showed that; There is a significant relationship between arm strength and smash ability in badminton of 0.674, there is a significant relationship between hand eye coordination and smash ability in badminton at 0.527, there is a significant relationship jointly between arm strength and hand eye coordination ability to smash. in the badminton game $F=22,258$

Keywords: Arm strength, hand eye coordination, smash ability

corresponding author: Udhinharuna3@gmail.com

Artikel Info:

Submitted: 19/10/2020

Revised : 27/10/2020

Accepted : 01/11/2020

Published: 16/11/2020

\section{(c) (7)}

Journal Coaching Education Sports is licensed under a Creatives Commons Attribution 4.0 International License. 


\section{A. Pendahuluan}

Peningkatan prestasi olahraga merupakan fenomena yang selalu menjadi tantangan, dan fenomena tersebut tidak habis-habisnya untuk dijadikan permasalahan sepanjang masa (Ardian et al., 2019). Sejalan dengan perkembangan ilmu pengetahuan dan teknologi, maka usaha yang dilakukan pada hakekatnya berdasarkan kajian dan ilmu pengetahuan (Bompa, 2011).

Olahraga merupakan aktivitas manusia yang sangat berpengaruh terhadap kesehatan bagi para pelakunya, apakah itu olahraga yang dilakukan dengan tujuan sebagai rekreasi, bersifat kompetitif, bahkan bertujuan ke arah prestasi (Pasaribu, 2016). Dengan perkembangan dan peningkatan pengetahuan dan teknologi, turut pula membawa peningkatan terhadap beberapa cabang olahraga yang telah berkembang dalam masyarakat pada umumnya (Widodo, 2018) dan Kabupaten Kotabaru pada khususnya

Dalam upaya merangsang pertumbuhan dan perkembangan fisik anak, pemerintah menempuh jalur pendidikan olahraga mengingat peran olahraga terhadap pertumbuhan dan perkembangan fisik sangat besar (Mustafa \& Dwiyogo, 2020). Dengan melakukan olahraga secara teratur otot akan menjadi kuat dan berkembang serta membuat organ-organ tubuh berfungsi dengan baik dan membuat badan menjadi segar serta mampu memberikan kesehatan kepada olahragawan (Pasaribu \& Mashuri, 2019). Oleh sebab itu, olahraga perlu makin ditingkatkan dan dimasyarakatkan sebagai salah satu cara pembinaan prestasi yang sekaligus dapat meningkatkan kesehatan jasmani dan rohani bagi setiap anggota masyarakat (Rizal \& Kasriman, 2020).

Semua ini perlu menjadi perhatian khusus, dimana olahraga sudah dijadikan tolak ukur tentang tinggi rendahnya budaya suatu bangsa. Sehingga dalam pola pembangunan dan pengembangan serta pembinaan olahraga di Indonesia mempunyai tujuan dan sasaran tertentu, yaitu tertuju pada masalah peningkatan prestasi olahraga (Harsono, 2013).

Cabang olahraga bulutangkis merupakan cabang olahraga yang sangat digemari oleh masyarakat pada umumnya, baik di perkotaan sampai ke pelosok pedesaan (Hanif \& Siregar, 2018). Karena kepopuleran cabang olahraga ini sehingga hampir disetiap sudut ruang yang ada di lapangan-lapangan bulutangkis walaupun dalam bentuk yang sangat sederhana. Khusus di SMPN 6 Kotabaru, presteasi yang telah dicapai pada olahraga bulutangkis belum dapat menunjukkan hasil yang memuaskan bila 
dibandingkan dengan beberapa sekolah di Kabupaten Kotabaru. Hal ini terbukti dari beberapa kejuaraan atau pertandingan yang pernah diselenggarakan, dimana siswa-siswi yang mengukuti kejuaraan tersebut seringkali gagal meraih prestasi yang memuaskan (Hanif \& Siregar, 2018).

Keadaan seperti yang dikemukakan merupakan masalah yang harus dicarikan jalan keluarnya, dan salah satu upaya yang dilakukan adalah melalui penelitian. Oleh sebab itu melalui penelitian ini menjadi wahana bagi penulis yang diharapkan dapat menunjang peningkatan prestasi olahraga bulutangkis. Smash atau biasa pula disebut dengan serangan, merupakan pukulan yang keras dan curam yang mengarah ke bidang lapangan lawan yang bertujuan untuk mematikan pertahanan lawan (Poole, 2011). Oleh karena itu, teknik smash sangat penting dikuasai oleh seorang pemain, karena pemain yang memiliki keterampilan smash yang tinggi mempunyai peluang yang besar untuk menjadi pemenang dalam suatu pertandingan (Halim, 2012).

Berbagai faktor yang dapat menyebabkan tidak optimalnya hasil pukulan smash yang dilakukan oleh seorang pemain, diantaranya adalah karena tidak didukung oleh kemampuan fisik, seperti; kekuatan lengan dan koordinasi mata tangan, dari setiap pemain bulutangkis (Singer, 2012). Permasalahan yang akan diteliti perlu dibatasi secara spesifik, agar tidak menimbulkan salah penafsiran dalam pengembangan kajian dalam penelitian yang sulit dianalisis.

Sesuai latar belakang masalah yang telah dikemukakan, maka permasalahan yang akan dicari jawabannya dirumuskan antara lain. Apakah ada hubungan antara kekuatan lengan terhadap kemampuan smash dalam permainan bulutangkis pada siswa kelas VIII SMPN 6 Kotabaru. Apakah ada hubungan antara koordinasi mata-tangan terhadap kemampuan smash dalam permainan bulutangkis pada siswa kelas VIII SMPN 6 Kotabaru. Apakah ada hubungan secara bersama sama antara kekuatan lengan dan koodinasi mata-tangan terhadap kemampuan smash dalam permainan bulutangkis pada siswa kelas VIII SMPN 6 Kotabaru.

Setiap aktivitas selalu memiliki tujuan, begitu pula dalam mengadakan penelitian. Tujuan penelitian adalah untuk memberikan gambaran secara empiris tentang hal-hal yang hendak diperoleh, dan hasil yang diperoleh melalui penelitian ini. Adapun tujuan yang ingin dicapai dalam penelitian ini. Untuk mengetahui apakah ada hubungan antara kekuatan lengan dengan kemampuan smash dalam permainan bulutangkis pada 
siswa kelas VIII SMPN 6 Kotabaru. Untuk

mengetahui apakah ada hubungan antara koordinasi mata-tangan dengan kemampuan smash dalam permainan bulutangkis pada siswa kelas VIII SMPN 6 Kotabaru Untuk mengetahui apakah ada hubungan antara kekuatan lengan dan koordinasi mata-tangan secara bersama-sama dengan kemampuan smash dalam permainan bulutangkis pada siswa kelas VIII SMPN 6 Kotabaru.

\section{B. Metode Penelitian}

Populasi penelitian ini adalah keseluruhan siswa kelas VIII SMPN 6 Kotabaru. Pengambilan sampel dengan teknik Simple Radom Sampling dengan cara undian, sehingga diperoleh jumlah sampel sebanyak 35 orang siswa putra kelas VIII SMPN 6 Kotabaru.

Jenis penelitian bersifat deskriptif (Sugiyono, 2015) yang bertujuan untuk mengetahui ada tidaknya hubungan antara kekuatan lengan dan koordinasi mata-tangan dengan kemampuan smash dalam permainan bulutangkis . Model desain penelitian yang digunakan secara sederhana dapat dilihat pada gambar berikut.

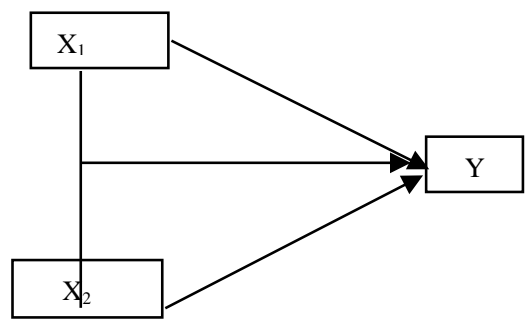

Gambar 1. Desain penelitian

Kekuatan lengan $\left(\mathrm{X}_{1}\right)$, Koordinasi matatangan $\left(\mathrm{X}_{2}\right)$, Kemampuan smash bulutangkis

Analisis data secara deskriptif dimaksudkan untuk mendapatkan gambaran umum tentang data yang meliputi rata-rata, standar deviasi, varians, nilai minimum, dan nilai maksimum (Arikunto, 2010). Uji normalitas data dengan menggunakan uji Kolmogorov Smirnov. Analisis secara infrensial digunakan untuk menguji hipotesis-hipotesis penelitian dengan menggunakan uji korelasi dan regresi. Jadi keseluruhan analisis data statistik yang digunakan pada umumnya menggunakan analisis statistik dengan bantuan komputer program SPSS 22 dengan taraf signifikan $95 \%$ atau $\alpha=0.05$.

Data-data yang akan dikumpulkan dalam penelitian ini sesuai dengan variabel yang terlibat, yakni data kekuatan lengan, data koordinasi mata-tangan, dan data kemampuan smash dalam permainan bulutangkis.

\section{Hasil dan Pembahasan}

Pengujian hasil analisis data meliputi deskriptif data, uji normalitas data, dan pengujian hipotesis. Data deskriptif meliputi 
perhitungan tentang rata-rata, standard deviasi, varians, data maksimum dan data minimum. Untuk memperjelas gambaran umum data akan disajikan dalam bentuk tabel. Selanjutnya untuk mengetahui apakah data hasil penelitian ini menyebar normal, maka dilakukan uji normalitas data terhadap teknik Shapiro-Wilk, sedangkan untuk pengujian hipotesis yang dimaksudkan untuk mengetahui adanya hubungan yang signifikan.

Uji koefisien determinan dimaksudkan untuk mengetahui seberapa besar hubungan kekuatan lengan dan koordinasi mata tangan terhadap kemampuan smash dalam permainan bulutangkis pada siswa kelas VIII SMPN 6 Kotabaru Untuk selengkapnya dapat dilihat pada lampiran. Sedangkan penyajian analisis data pada bagian ini hanya dalam bentuk rangkuman.

Hasil rangkuman hasil analisis deskriptif pada penelitian ini dapat dilihat pada tabel 1 .

Tabel 1. Deskriptif data kekuatan lengan dan koordinasi mata tangan terhadap kemampuan smash pada permainan bulutangkis

\begin{tabular}{lll}
\hline $\begin{array}{l}\text { Kekuata } \\
\text { n lengan }\end{array}$ & $\begin{array}{l}\text { Koordina } \\
\text { si mata } \\
\text { tangan }\end{array}$ & $\begin{array}{l}\text { Kemampu } \\
\text { an smash }\end{array}$ \\
\hline
\end{tabular}

\begin{tabular}{lccc}
\hline Sampel & 35 & 35 & 35 \\
Max & 20 & 18 & 12 \\
Min & 8 & 7 & 5 \\
Averag & 13,62 & 12,88 & 8,02 \\
e & 3,396 & 3,312 & 2,175 \\
STDV & & & \\
\hline
\end{tabular}

Berdasarkan Tabel 1. dapat dikemukakan bahwa data kekuatan lengan mempunyai rata-rata 13,62 dan standart deviasi adalah 3,396 Dilihat dari sebaran datanya, data minimun 8 sedangkan data maksimum 20, Data koordinasi mata tangan mempunyai rata-rata 12,88 dan standart deviasi adalah 3,312 Dilihat dari sebaran datanya, data minimun 7 sedangkan data maksimum 18, Data kemampuan smash pada permainan bulutangkis mempunyai rata-rata 8,02 dan standart deviasi adalah 2,175 Dilihat dari sebaran datanya, data minimun 5 sedangkan data maksimum 12.

Selanjutnya dilakukan uji persyaratan yaitu normalitas terhadap uji Kolmogorovsmirnov Test pada taraf signifikan $5 \%$ atau $\alpha$ $=0,05$. Dari hasil uji Kolmogorov-smirnov Test yang dilakukan, diperoleh hasil sebagaimana yang terlampir. Untuk hasil perhitungan dapat dilihat pada tabel 2 .

Tabel 2. Rangkuman hasil uji normalitas data kekuatan lengan dan koordinasi mata tangan terhadap kemampuan smash pada permainan bulutangkis 


\section{Hubungan Antara Kekuatan Lengan dan Kordinasi Mata-Tangan Terhadap Kemampuan Smash dalam Permainan Bulutangkis \\ E-ISSN: 2722-3450}

\begin{tabular}{clccc}
\hline No & Variabel & Statistik & Sig & Ket. \\
\hline 1 & Kekuatan & 0,115 & 0.200 & Normal \\
2 & lengan & 0.126 & 0.171 & Normal \\
3 & Koordinasi & 0,110 & 0,200 & Normal \\
& mata tangan & & & \\
& Kemampuan & & & \\
& smash pada & & & \\
& permainan & & & \\
\hline & bulutangkis & & & \\
\hline
\end{tabular}

Berdasarkan tabel tersebut yang merupakan rangkuman hasil pengujian normalitas data pada tiap-tiap variabel penelitian. Dalam pengujian normalitas data kekuatan lengan diperoleh nilai probabilitas $=0.200$ lebih besar dari pada nilai $\alpha=0,05$ atau pada taraf siginifikan $5 \%$. Dengan demikian data koordinasi mata kaki yang diperoleh berdistribusi normal. Dalam pengujian normalitas data koordinasi mata tangan diperoleh nilai probabilitas $=0.171$ lebih besar dari pada nilai $\alpha=0,05$ atau pada taraf siginifikan 5\%. Dengan demikian data kelincahan yang diperoleh berdistribusi normal. Dalam pengujian normalitas data kemampuan smash dalam permainan bulutangkis diperoleh nilai probabilitas $=$ 0.200 lebih besar dari pada nilai $\alpha=0,05$ atau pada taraf siginifikan 5\%. Dengan demikian data kemampuan smash pada permainan bulutangkis yang diperoleh berdistribusi normal.

Koefisien korelasi menunjukan hubungan, antara variabel independen 
smash) terhadap variabel $\mathrm{X}_{2}$ (koordinasi mata tangan) diperoleh nilai 0.527 dan nilai sig 0.001 Hasil ini mengindikasikan bahwa terdapat hubungan korelasi antara variabel $\mathrm{Y}$ (kemampuan smash) terhadap variabel $\mathrm{X}_{2}$ (koordinasi mata tangan), yang ditunjukkan terhadap nilai sig $(\mathrm{p})<0.05$.

Adapun rangkuman hasil analisis korelasi ganda kekuatan lengan dan koordinasi mata tangan dengan kemampuan smash dapat dilihat pada tabel 4.

Tabel 4. Rangkuman hasil analisis korelasi ganda kekuatan lengan dan koordinasi mata tangan dengan kemampuan smash

\begin{tabular}{lccccc}
\hline $\begin{array}{l}\text { Variabe } \\
1\end{array}$ & $\mathrm{R}$ & $\mathrm{R}^{2}$ & $\mathrm{~F}$ & $\mathrm{P}_{\text {value }}$ & $\mathrm{Ket}$ \\
\hline$\left(\mathrm{X}_{1}\right)$, & & & & & \\
$\left(\mathrm{X}_{2}\right)$ & 0,7 & 0,5 & 22,2 & 0,00 & Signifi \\
terhada & 63 & 82 & 58 & 0 & kan \\
$\mathrm{p}(\mathrm{Y})$ & & & & & \\
\hline
\end{tabular}

Berdasarkan tabel tersebut terlihat bahwa hasil perhitungan korelasi ganda, diperoleh nilai korelasi hitung, berarti ada hubungan yang signifikan antara kekuatan lengan dan koordinasi mata tangan dengan kemampuan smash yaitu $(\mathrm{R})=0,763(\mathrm{P}<0.05)$ dengan nilai koefisien determinasi $\left(\mathrm{R}^{2}\right)=0,582$ atau $58,2 \%$, setelah dilakukan uji signifikan dengan menggunakan uji $\mathrm{F}$ diperoleh $\mathrm{F}_{\text {hitung }}=$
22,258 ( $\left.\mathrm{P}_{\text {value }}<\alpha 0,05\right)$. Dengan demikian apabila pemain bulutangkis memiliki kekuatan lengan dan koordinasi mata tangan secara bersama dan menguasai teknik smash dengan baik, maka akan diikuti pula dengan kemampuan permainan bulutangkis yang lebih maksimal. Ada tiga hipotesis yang akan diajukan dalam penelitian ini. 1) Hasil analisis data diperoleh nilai korelasi hitung ( $\mathrm{r})=0,674(\mathrm{P}<0.05)$, maka dengan demikian $\mathrm{H}_{\mathrm{o}}$ ditolak dan $\mathrm{H}_{1}$ diterima dengan demikian dapat dijelaskan bahwa ada hubungan yang signifikan antara kekuatan lengan dengan kemampuan smash pada permainan bulutangkis; 2) Hasil analisis data diperoleh nilai korelasi hitung $(r)=0,527$ ( $\mathrm{P}<0.05$ ), maka dengan demikian $\mathrm{H}_{\mathrm{o}}$ ditolak dan $\mathrm{H}_{1}$ diterima dengan demikian berarti ada hubungan yang signifikan antara koordinasi mata tangan dengan kemampuan smash pada permainan bulutangkis; 3) Hasil analisis data diperoleh nilai korelasi hitung $(\mathrm{R})=0,763$ ( $\mathrm{P}<0.05$ ), maka dengan demikian $\mathrm{H}_{\mathrm{o}}$ di tolak dan $\mathrm{H}_{1}$ diterima dengan demikian berarti ada hubungan yang signifikan antara kekuatan lengan koordinasi mata tangan secara bersama dengan kemampuan smash pada permainan bulutangkis.

Dari hasil analisis data korelasi ganda, diperoleh nilai $\mathrm{R}$ hitung ( $\mathrm{Ro}$ ) sebesar $=0,556$, dengan $\mathrm{F}$ diperoleh sebesar $=22,258$ 
$\left(\mathrm{P}_{\text {value }}<\alpha 0,05\right)$. Maka $\mathrm{H}_{0}$ ditolak dan $\mathrm{H}_{1}$ diterima, Hal ini berarti ada hubungan yang signifikan secara bersama-sama kekuatan lengan dan koordinasi mata tangan dengan kemampuan smash pada permainan bulutangkis. Nilai koefisien determinasi $\left(\mathrm{R}^{2}\right)$ yang diperoleh $=0,582$, hal ini berarti bahwa $58,2 \%$ kemampuan smash pada cabang olahraga bulutangkis dijelaskan oleh kekuatan lengan dan koordinasi mata tangan, sedangkan sisanya $41,8 \%$ dijelaskan oleh variabel lain yang tidak diamati dalam penelitian ini. Hal ini mengandung makna bahwa, apabila siswa memiliki kekuatan lengan dan koordinasi mata tangan yang baik, maka akan diikuti dengan kemampuan smash yang baik pula.

Berdasarkan hasil pengujian hipotesis menunjukkan bahwa dari ke tiga hipotesis diterima. Hasil hipotesis-hipotesis tersebut adalah sebagai berikut: 1) ada hubungan yang signifikan kekuatan lengan terhadap kemampuan smash pada permainan bulutangkis siswa kelas VIII SMPN 6 Kotabaru 2) ada hubungan yang signifikan koordinasi mata tangan terhadap kemampuan smash pada permainan bulutangkis siswa kelas VIII SMPN 6 Kotabaru 3) ada hubungan yang signifikan kekuatan lengan dan koordinasi mata tangan secara bersamasama terhadap kemampuan smash pada permainan bulutangkis siswa kelas VIII SMPN 6 Kotabaru dan dapat diartikan bahwa kekuatan lengan dan koordinasi mata tangan mempunyai hubungan terhadap kemampuan smash.

Hasil analisis data melalui statistik diperlukan pembahasan teoritis yang berstandar pada teori-teori dan kerangka berpikir yang mendasari penelitian ini. Hasil uji hipotesis pertama: Ada hubungan yang signifikan kekuatan lengan terhadap kemampuan smash. Hasil analisis statistik menunjukkan bahwa ada hubungan yang signifikan antara kekuatan lengan terhadap kemampuan smash. Apabila hasil penelitian ini dikaitkan terhadap teori dan kerangka berpikir yang mendasarinya, maka pada dasarnya hasil penelitian ini mendukung dan memperkuat teori dan hasil-hasil penelitian terdahulu yang sudah ada. Jika kekuatan lengan dianalisis dari segi fisik yang terlibat didalamnya, maka unsur koordinasi kekuatan lengan mendukung kemampuan smash. Seorang siswa yang memiliki kekuatan lengan yang baik akan terhadap sendirinya mampu melakukan akselerasi smash dengan baik pula (Handayani, 2018). Dalam hal ini, kekuatan lengan akan memberikan sumbangan yang berarti dalam permainan bulutangkis. Oleh karena itu, dapat disimpulkan bahwa untuk 
menghasilkan kemampuan smash pada permainan bulutangkis secara maksimal, maka kekuatan lengan sangat memegang peranan penting (Ahmad et al., 2017).

Hasil uji hipotesis kedua: Ada hubungan yang signifikan koordinasi mata tangan terhadap kemampuan smash. Hasil analisis statistik menunjukkan bahwa ada hubungan yang signifikan antara koordinasi mata tangank terhadap kemampuan smash. Apabila hasil penelitian ini dikaitkan terhadap teori dan kerangka berpikir yang mendasarinya, maka pada dasarnya hasil penelitian ini mendukung dan memperkuat teori dan hasil-hasil penelitian terdahulu yang sudah ada. Jika koordinasi mata tangan dianalisis dari segi fisik yang terlibat didalamnya, maka unsur koordinasi mata tangan mendukung kemampuan smash (Habibie et al., 2019). Seorang siswa yang memiliki koordinasi mata tangan yang baik akan sendirinya mampu smash dengan baik dan maksimal sehingga dalam bermain bulutangkis dapat memberikan sumbangan yang positif terhadap tim (Habibie et al., 2019).

Hasil uji hipotesis ke tiga: Ada hubungan yang signifikan kekuatan lengan dan koordinasi mata tangan terhadap kemampuan smash. Hasil analisis statistik menunjukkan bahwa ada hubungan yang signifikan antara kekuatan lengan dan koordinasi mata tangan terhadap kemampuan smash. Apabila hasil penelitian ini dikaitkan terhadap teori dan kerangka berpikir yang mendasarinya, maka pada dasarnya hasil penelitian ini mendukung dan memperkuat teori dan hasil-hasil penelitian terdahulu yang sudah ada. Apabila siswa memiliki kekuatan lengan dan koordinasi mata tangan terhadap kemampuan smash pada permainan bulutangkis yang baik maka akan mampu melakukan pukulan suttlecook dan smash yang maksimal terhadap permainan bulutangkis (Alvian \& Nuruddin, 2019). Oleh sebab itu pada dasarnya ketika seseorang ingin mendapatkan hasil yang maksimal dalam smash dalam permainan bulutangkis maka aspek yang utama yang harus dimiliki yaitu kekuatan lengan dan koordinasi mata tangan karena kedua komponen tersebut memberikan pengaruh yang besar sehingga mampu memberikan hasil yang maksimal ketika seseorang bermain bulutangkis (Yusuf, 2015).

\section{Kesimpulan}

Adapun kesimpulan di dalam penelitian ini secara sederhana. Ada hubungan yang signifikan kekuatan lengan terhadap kemampuan smash dalam permainan bulutangkis pada siswa kelas VIII SMPN 6 
Kotabaru sebesar 0,455. Ada hubungan yang signifikan koordinasi mata tangan terhadap kemampuan smash dalam permainan bulutangkis pada siswa kelas VIII SMPN 6 Kotabaru sebesar 0,587. Ada hubungan yang signifikan kekuatan lengan dan koordinasi mata tangan secara bersama sama terhadap kemampuan smash dalam permainan bulutangkis pada siswa kelas VIII SMPN 6 Kotabaru sebesar $\mathrm{F}=8,811$.

\section{Daftar pustaka}

Ahmad, S., Suratmin, \& Dharmadi, M. A. (2017). Hubungan Power Lengan Dan Kelincahan Dengan Pukulan Smash Bulutangkis Pada Siswa Peserta Ekstrakurikuler Bulutangkis SMA Negeri 2 Gerokgak Tahun 2017. Jurnal Pendidikan Kepelatihan Olahraga Undiksha, $8(2)$. https://doi.org/http://dx.doi.org/10.2388 7/jjpko.v9i1.12455

Alvian, R., \& Nuruddin, A. A. (2019). Hubungan Kekuatan Otot Lengan Dan Kekuatan Otot Perut Terhadap Penguasaan Teknik Dasar Renang Gaya Dada. JPOS (Journal Power Of Sports), 2(2),

https://doi.org/http://doi.org/10.25273/j

pos.v2i 2.4970

Ardian, A., Purwanto, S., \& Alfarisi, D. S.
(2019). Hubungan Prestasi Belajar Siswa Kelas Khusus Olahraga Dengan Kecerdasan Emosional The Relationship Of Learning Achievement Special Students With Emotional Intelligence. Jurnal Keolahragaan, $7(2), \quad 126-134$. https://doi.org/https://doi.org/10.21831/ jk.v7i2.28103

Arikunto, S. (2010). Prosedur Penelitian Suatu Pendekatan Praktik (edisi revisi 2010). In Jakarta: Rineka Cipta (10th ed.).

Bompa. (2011). Theory And Of Training The Key Perpomance,. Hunt Publishing Company.

Habibie, M., Widiastuti, W., \& Nuriani, S. (2019). Pengaruh Metode Latihan Dan Kordinasi Mata - Kaki Terhadap Keterampilan Shooting Dalam Sepakbola. Multilateral: Jurnal Pendidikan Jasmani Dan Olahraga, $18(1)$ $25-31$. https://doi.org/http://dx.doi.org/10.2052 7/multilateral.v18i1.6564

Halim, N. I. (2012). Tes dan Pengukuran dalam Bidang Olahraga. Badan Penerbitan Universitas Negeri Makassar.

Handayani, W. (2018). Hubungan Koordinasi Mata Tangan dan Kekuatan 
Otot Lengan dengan Ketepatan Hasil Servis Forehand. Wahana Didatik, $16(2)$, 256-266.

https://doi.org/http://dx.doi.org/10.3185

1/wahanadidaktika.v16i2.2052

Hanif, S., \& Siregar, N. M. (2018). MODEL LATIHAN KETERAMPILAN FOOTWORK ( RD ) UNTUK ATLET BULUTANGKIS PEMULA USIA 13-15 TAHUN. 4(1), 55-62.

Harsono. (2013). Coaching dan Aspek-Aspek Psikologi dalam Coaching. Dedikbud Dirjen Dikti.

Mustafa, P. S., \& Dwiyogo, W. D. (2020).

Kurikulum Pendidikan Jasmani, Olahraga, dan Kesehatan di Indonesia Abad 21. JARTIKA Jurnal Riset Teknologi Dan Inovasi Pendidikan, $3(2)$, 422-438. https://doi.org/10.36765/jartika.v3i2.26 8

Pasaribu, A. M. N. (2016). Pengaruh Gaya Menagajar dan Motivasi Belajar Passing Bawah dalam Permainan Bola Voli pada Siswa SMP Kelas VIII. Jurnal SPORTIF: Jurnal Penelitian Pembelajaran, 2(2), 85-97. https://doi.org/https://doi.org/10.29407/ js_unpgri.v2i 2.510

Pasaribu, A. M. N., \& Mashuri, H. (2019). The role of rhythmic gymnastics for physical fitness for elementary school students. Jurnal SPORTIF: Jurnal Penelitian Pembelajaran, 5(1 SEArticle), 89-97. https://doi.org/10.29407/js_unpgri.v5i1. 12551

Poole, J. (2011). Teknik permainan Bulutangkis. Akademika Pressindo.

Rizal, B. T., \& Kasriman. (2020). Pengaruh Gaya Mengajar Dan Koordinasi Mata Tangan Terhadap Keterampilan Smash Bola Voli. Jurnal Maenpo: Jurnal Pendidikan Jasmani Kesehatan Dan Rekreasi, 10(2), 72-83. https://doi.org/https://doi.org/10.35194/ jm.v10i2.1065

Singer. (2012). Kinesiologi. Dedikbud Dirjen Dikti.

Sugiyono, P. D. (2015). Metode Penelitian dan Pengembangan. Res. Dev. D.

Widodo, A. (2018). Makna Dan Peran Pendidikan Jasmani Dalam Pembentukan Insan. Jurnal Motion, $9(1), \quad 53-60$. https://www.researchgate.net/publicatio n/329442726_MAKNA_DAN_PERAN _PENDIDIKAN_JASMANI_DALAM _PEMBENTUKAN_INSAN_YANG_ MELEK_JASMANIAHTER-

LITERASI_JASMANIAHNYA

Yusuf, M. A. (2015). Kontribusi Kekuatan 
Otot Lengan dan Koordinasi Mata -

Tangan Terhadap Pukulan Smash pada

Bulutangkis Kategori Remaja Putra.

Jurnal Kesehatan Olahraga, 3(1), 22-

30.

https://jurnalmahasiswa.unesa.ac.id/ind

ex.php/jurnal-kesehatan-

olahraga/article/view/11161/10659 